\title{
Health and Illnes Concept in Elderly Age in Munte Village, Munte District, Karo Regency
}

\author{
Mia Audia Br Kaban and Nurman Achmad \\ Universitas Sumatera Utara, Jalan, Dr sofyan no 1, Medan, Indonesia \\ Miaaudia679@gmail.com
}

Keywords: Elderly Age, Healthy, Sick.

\begin{abstract}
This study discusses the concept of health and illness in the elderly in Munte Village, Munte District, Karo Regency. The purpose of this study was to see how the elderly respond in dealing with disease and to see what things are done to process the prevention and cure of a disease. The method used in this research is ethnography with a qualitative approach with the aim of systematically describing cultural characteristics more deeply in their own space and time. The methods used in data collection are participatory observation and unstructured interviews and use interview guidelines. The results of the study were to see how the elderly interpret health in old age. Traditional medicine that is so attached to their daily lives is a knowledge that is passed down from generation to generation. The role of the family is very important in supporting the health of the elderly both from a social, economic and psychological perspective.
\end{abstract}

\section{INTRODUCTION}

Socio-cultural anthropologists and biological anthropologists are increasingly paying attention to cross-cultural concerns about health systems, as well as on bioecological and socio-cultural factors that affect health and the onset of disease, both now and throughout the history of human life. Anthropologists call this sub-discipline medical anthropology (Foster and Anderson, 1986).

Conceptually, health anthropology will teach in one context with one part called the biology pole and the second part called the socio-cultural pole. In biology pole, there are anthropologists whose main concern is about human growth and development, the role of disease in human evolution and paleopathology (the study of ancient diseases). The direction of the socio-cultural poles is concerned with the traditional medical system (ethnomedicine), the problems of health workers and their professional preparation. Ill behavior, the relationship between the patient doctor and the dynamics of introducing Western health care to traditional societies.

Health anthropology is a term used by anthropologists to describe research whose purpose (1) is a comprehensive definition and interpretation of the cultural interrelationships between past and present human behavior with the practical health degree of knowledge and (2) professional participation in programs aimed at improving health status through a greater understanding of the relationship between bio-socio-cultural symptoms and health, as well as through changes in healthy behavior in a direction that are believed to promote the better.

The United Nations or UN in 2050 predicts that Indonesia will become the country with the tenth largest number of elderly people in the world (http: m.cnnindonesia.com) within the next three decades, the proportion of elderly people will be greater than the proportion of underage 14 years (Tiara, 2018).

As a developing country, Indonesia faces many challenges in improving the health and well-being of the elderly, on the one hand increasing life expectancy is good for one of the nation's health indicators, but on the other hand it also has an impact on disease transition that impacts aging. It takes serious attention from the government, health workers, and researchers to encourage various programs to improve the health and welfare of the elderly in Indonesia. The health of the elderly is also affected by (1) low levels of education, (2) limited employment opportunities, (3) poor public facilities / infrastructure, (4) lack of government attention, (5) a shift in socio-cultural values, and (6) the low quality of human resources is the cause of health problems for the elderly in Indonesia.

The number of elderly will continue to increase every year, including the increasing socioeconomic level of society, the health sector, and the increasing level of the present. Improving elderly tourism is often not balanced with physical activity that is 
accurate as the subjective perception of the individual (elderly) to physical and physical health and social and environmental functions become the benchmark of health and living in old age (Carlos, 2012).

Various life problems faced by the elderly both physically and psychosocially will interact with each other (Marlita, Saputra, \& Yamin, 2018). [31 Physical condition entering old age will definitely decrease. This decrease in physical condition will later affect the psychic condition of the elderly, readiness of the elderly in facing multi-dimensional problems, namely physically, psychologically, economically, socially, and spiritually, ideally the elderly are able to complete their developmental tasks. The journey of elderly life as well as other periods in development have developmental tasks that must be lived in their lifetime (Marlita, 2018).

With age, physiological function decreases due to degenerative process (aging), so that noncommunicable diseases appear in the elderly. In addition, the degenerative process decreases the immune system so that it is susceptible to infectious disease infections. Morbidity rates are the proportion of the elderly population who have experienced health problems to disrupt their daily activities over the past month (Suiraoka. 2012).

Various health programs are carried out to support the health of the elderly, such as providing Integrated Health Service Post or Posyandu for the elderly, and home care, but this is poorly understood and works well in Indonesia. Care and family roles are needed by the elderly to maintain the quality of life of the elderly to maintain the quality of life for widows or widowers to always be good.

According to the Law of the Republic of Indonesia Number 13 of 1998 concerning Elderly Welfare, what is meant by Elderly (Elderly) is someone who has reached the age of 60 years and over. Behind the success of increasing the UHH (Life Expectancy), there are challenges that must be watched out, namely in the future Indonesia will face a triple burden, namely in addition to increasing birth rates and disease burdens (infectious and noncommunicable), there will also be an increase in the dependency burden of the population of unproductive age groups. In terms of health, the elderly will experience a decrease in health status both naturally and as a result of disease.

Within five decades, the percentage of elderly people in Indonesia has approximately doubled (1971-2017), namely to 8.97 percent (23 million), where female elderly is about one percent more than male elderly (9.47). percentage versus 8.48 percent (BPS, 2017). The increasing number of elderly people each year automatically has an effect on the increasing number of households inhabited by the elderly. Indonesia does not yet have a good and complete system like developed countries so that the role of the family in caring for the elderly is very large.

In the North Sumatra Region, the proportion of elderly people varies widely, ranging from 4.06 percent, namely Labuhan Batu Selatan Regency to 11.50 percent in Samosir Regency. Other areas with the largest proportion of the elderly population are Toba Samosir, Humbang Hasundutan and North Tapanuli Regencies. The high proportion of the elderly population in the area is closely related to the phenomenon of urbanization out of the young population on the grounds of getting a better life.

Karo Regency, which is one of the districts in North Sumatra, is predominantly occupied by the Karo ethnic group. The number of elderly people in this Regency is the 6th largest in the North Sumatra region with the first rank, namely Samosir Regency. Karo Regency consists of 17 districts, one of which is Munte district. Munte district consists of 23 villages that will be the research sites, namely Munte Village.

A community or ethnic group has local knowledge about the concepts of health and illness, this will also recognize in developing a set of beliefs, cognition, beliefs and perceptions that are consistent with their environment or cultural context (Rahman, 2013). The subject of this research itself discusses the concept of health and illness in the elderly for the Karo ethnic who live in Munte village.

Karo ethnoscience in terms of the concept of health and illness cannot be separated from their ethnomedicine. This ethnomedicine grows and develops within an ethnic group in understanding disease and the meaning of health according to their cultural experience. The ethnoscience approach does not question the right or wrong knowledge of a society, here try to understand people's knowledge through their own views. Health research in the field of anthropology is research that focuses on aspects of health from a socio-cultural perspective.

Ethnomedicine is a part of health anthropology, which specializes in conducting traditional studies on non-western medicine, or on traditional medical practices that are not derived from medical concepts. Each ethnic group has a traditional medical system that develops from its own culture. In the use of Ethnomedicine, it is also related to Health Anthropology. Where is healthy behavior as a rational response or with a certain view of life or cognitive orientation from the citizens of each society for the perceived causes of disease. In health anthropology it emphasizes a cross-cultural perspective, emphasizing the common elements that 
underlie all aspects of the health system, regardless of cultural context.

In non-western societies it is known that preventive medicine (public health) is different from western health, namely curative medicine (clinics, part of the private sector). Preventive medicine is more about the actions of individuals than those of legal entities. It is the behavior of individuals who logically follow the concept of the cause of disease, which while explaining why people get sick, also teaches about what to do to avoid the disease. Preventive medicine for the elderly, especially for the elderly, is also part of the individual's behavior so that they seem to know the cause of the disease and make medicine to prevent and even treat the disease by using plants and even animals for medicine for the elderly.

\section{RESEARCH METHOD}

This study uses qualitative research methods (ethnography) to collect research data. Spradley's qualitative research or better known as ethnographic qualitative research is a qualitative study of individuals or groups with the aim of systematically describing cultural characteristics more deeply in their own space and time.

Ethnography is the main part of anthropological research which aims to provide a detailed description of the various cultural activities of a particular community group (Endraswara, 2017).

According to Spradley (1980) in Endraswara (2017) ethnography is a job to describe a culture. This description of culture is obtained through direct observation activities or through fieldwork as a characteristic of cultural anthropology.

In this study, there are two kinds of data to be collected, namely primary data and secondary data. Primary data is obtained from field research so that the expected data can be achieved objectively and factually. The way to get primary data is by participatory observation and interviews. Meanwhile, secondary data is needed to support primary data. In this study, secondary data was obtained through data analysis in the form of literature study, documentation, online / internet sources and other relevant sources.

In addition, those who became informants in this study were key informants, namely (a) young elderly between the ages of 60-69 years, (b) middle seniors between the ages of 70-79 years, (c) elderly seniors between the ages of 80 onwards; as well as regular informants, namely the Munte community such as the village head, village head staff, children and elderly relatives

\section{RESULT AND DISCUSSION}

The concept of health and illness is not really absolute and universal because there are other individual factors such as body condition and social factors such as social interactions. In the context of the concept of health and illness, this will affect each other. Health and illness problems are processes related to the ability to adapt both psychologically, biologically and socially. The concept of Healthy can be interpreted by different people, based on the community. As it is said that the Karo people have knowledge about medicine and different points of view, it will concretely create a difference in understanding of the concept of health which is seen emotionally/emic ally and ethically.

Emic and Ethics are two kinds of viewpoints in ethnography. Emic (native point of view), for example, tries to explain a phenomenon in society from the perspective of the community itself. Ethics is the use of an outsider's point of view. As the elderly see the concept of health and sickness from their own point of view and view the concept of health and sickness towards others.

Health when viewed based on an ethical approach, namely (1) The concept of health from a physical perspective, namely health related to one's body or body. In this case, the elderly in Munte village still do many farming activities and pay attention to their physical health by making traditional medicines; (2) The concept of health from an emotional perspective, namely the ability to recognize emotions such as anger, pleasure, fear, and how to express emotions quickly; (3) The concept of health from a social perspective means the ability to make and maintain relationships with other people such as family; (4) The concept of health is seen from the spiritual aspect, which is related to religious beliefs and practices, relating to good deeds, personally, principles of behavior, and how to achieve peace and feel peaceful in solitude.

Health based on an emic approach, for the elderly in Munte village who carry their cultural concept, there are different views in responding to the concept of ethical health. This is because there are different views on the concept of being healthy, although it can be seen that an elderly person is ethically unhealthy, but can still do other social activities. This means that the elderly can declare himself healthy.

Meanwhile, Illness is a person's view or perception when he feels that his health is disturbed. Pain can be interpreted differently based on scientific knowledge and can be seen based on the cultural knowledge of each person with his culture. Illness based on an ethical viewpoint, that is, scientifically, disease is defined as a disturbance in 
the physiological function of an organism as a result of infection or pressure from the environment, so the disease is objective. Generally, the elderly in Munte village view someone as sick, if the elderly can no longer carry out their daily duties optimally or lose their strength so they have to stay in bed. Whereas emotionally sick can be seen based on the understanding of the cultural concept of the community with its culture as stated by Foster and Anderson (1986) who found the concept of disease in traditional societies which they traced in the literature on ethnomedicine, that the concept of disease in non-western societies is one of them, namely Naturalistic, where illness (illness) is described in systematic terms and not personal.

In terms of maintaining health, traditional ethnic communities have a knowledge of medicine that has been passed down from their ancestors. Karo elderly live in Karo district using ethnomedicine to support their health in old age apart from the sophistication of modern medicine. The Karo land area is indeed famous for its wealth of spices so that its people are synonymous with traditional medicine that comes from nature. Many of these herbs are processed for traditional medicines such as massage oil, parem "kuning", "dilat-dilat", "tawar" and even animals are used to make traditional Karo medicines such as "centipede or Lipan" massage oil.

The author believes that there are still many Elderly Karo People who still use traditional medicines in their daily lives. According to the elderly, one of the driving factors for their longevity is the use of traditional medicines in addition to other factors such as religion, psychology, economy and others.

The role of the family is very much needed in supporting the health of the elderly. The care carried out by the elderly includes physical care, psychological care, social care and spiritual care. Treatment is carried out to support the health of the elderly without reducing the independence of the elderly, comfort also arises if the child takes care of the elderly himself if the elderly is sick, but not infrequently because in the karo culture of knowing Rebu, reluctance and awkwardness will arise if the care is the son-in-law. Most of the elderly in Munte prefer to live with their husbands or be independent in their own homes. Similar to Nurman's research in 2017, Karo Lansia Activities in Lingga Village, Tanah Karo Regency, North Sumatra, Indonesia that Karo Seniors are more independent, happy to live alone (Achmad. 2017).

In relation to the role of the family, there is a customary action in the form of appreciation for the elderly, husband and wife who live long, such as the informant who wrote the interview that he was presented with a golden party from his son for their 50th year of marriage, the children held the party as a tribute to the father and mother who was still healthy and be happy at the end of his life. In the Karo culture, there are 3 traditional processions for the elderly, namely Ngembahken Nakan, Mark Toktok, Ciken, Bulang, Tudung.

\section{CONCLUSION}

When developing countries Indonesia is proud of the way of health and welfare of the elderly. On the one hand increasing life expectancy brings for one of the nation's health indicators, but on the other hand it also has an impact on diseases that have an impact on alert. Elderly health is also getting higher low education, limited employment, poor public facilities / infrastructure, lack of government attention, socio-cultural values, and low human resources become problems of elderly health. The care and role of the family is very burdened by the elderly to live the lives of the elderly to live widows or widowers to always be good. In addition, the elderly change roles in the family, socioeconomic and social communities which make changes in the new environment and interact with new people.

The concept of healthy and sick is universal, this is very tailed by socio-cultural factors in which to live and repent with those around it. The problem of illness and healthy birth of a process in a way or one of human beings together with the environment either biologically, re-living or socio-cultural.

Self-health medicine with the word good medicine will be one of the efforts to self-deify from the disease. When it comes to health, traditional ethnic communities have come to know about what their ancestors inherited. Life is mutual with nature and ethnic society traditional medicine from nature.

\section{REFERENCES}

Achmad, N., \& Muda, I. (2017). Economic Activities of Karo Older Adults in Lingga Village, Tanah Karo Regency, North Sumatera, Indonesia.

Anderson, (1986). Health Anthropology. UI Press. Jakarta, Cetakan Pertama.

Badan Pusat Statistik (2017). Statistik Penduduk Lanjut Usia. Jakarta

Carlos, 2012. Education based on precede-proceed on quality of life in elderly. Global Journal of Health Science. Vol.6. No.6. 178-84

Endraswara. (2017). Ethnography Literatures. Morfalingua. Yogyakarta.

Marlita, L., Saputra, R., \& Yamin, M. (2018). Faktor-Faktor yang Mempengaruhi Tingkat 
Kemandirian Lansia dalam Melakukan Activity Daily Living (ADL) di UPT PSTW Khusnul Khotimah. Jurnal Keperawatan Abdurrab, 1(2), 64-68.

Rahman. (2013). Ethnomedicine Studies on Tugutil in Mahalmera System Personalistic and Naturalistic (Thesis as the requirement for Master Degree Program). Post Graduate Program Faculty of Cultural Sciences University of Gajah Mada. Yogyakarta.

Statistik, B. P. (2014). Survei Sosial Ekonomi Nasional (SUSENAS) Kor, 2014.

Suiraoka, I. P. (2012). Penyakit degeneratif. Yogyakarta: Nuha Medika, 45-51.

Tiara, L. (2018). Hubungan Fungsi Keluarga Dengan Kualitas Hidup Pada Lansia Di Posdaya Sumanik Sehat Nagari Sumanik Kec. Salimpaung Kab. Tanah Datar Sumatera Barat (Doctoral Dissertation, Universitas Andalas). 